\title{
O desejo humano em imortalizar-se
}

The human desire to immortalize-itself

\author{
TIAGO XAVIER ${ }^{1}$
}

Resumo: Este trabalho pretende mostrar que devido aos avanços da ciência e tecnologia, já se fala na possibilidade da imortalidade do corpo por meio da longevidade, sendo vista por muitos como fundamental para a evolução da raça humana.

Palavras-chave: Longevidade. Imortalidade do corpo. Aprimoramento.

Abstract: This work intends to show that due to the advances of science and technology, the possibility of immortality of the body through longevity is already spoken up, being considered by many as fundamental for the evolution of the human race.

Keywords: Longevity. Body immortality. Enhancement.

\section{Introdução}

A corrida espacial dos anos 60 entre Estados Unidos e União Soviética contribuiu para o avanço da ciência e tecnologia. Tal ampliação resultou em grandes descobertas, como por exemplo, a do britânico Francis Harry Compton Crick (19162004) e do estadunidense James Dewey Watson acerca da estrutura de dupla hélice do DNA, que ajudou a esclarecer os mecanismos de herança genética, abrindo caminho para todos os estudos genéticos que conhecemos hoje $\mathrm{e}^{2}$.

Os trangênicos, o sequenciamento de genomas e os tratamentos para enfermidades hereditárias só foram possíveis por conta desta importante descoberta, uma vez que os cientistas "descobriram nada mais nada menos do que a estrutura do DNA, a molécula que, sozinha, carrega todas as informações necessárias para a formação de todos os seres vivos” (ESCOBAR, 2004).

Essa descoberta foi tão relevante que, se não fosse ela, "não existiria o sequenciamento do genoma humano, a clonagem, o teste de paternidade ou boa parte dos alimentos e medicamentos que consumimos" (ESCOBAR, 2004), uma vez que contribuem para o aumento expressivo na expectativa de vida da população mundial, estando diretamente associado a melhorias das condições de vida.

\footnotetext{
${ }^{1}$ Bacharel, Licenciatura Plena e Mestrado em Filosofia pela Universidade Federal do Rio Grande do Norte (UFRN). Doutorando em Filosofia pela mesma instituição. E-mail: sophosxavier@hotmail.com ${ }^{2}$ Vale mencionar que embora algumas literaturas se refiram a Crick e Watson como sendo os únicos pioneiros nessa descoberta, é a cientista britânica Rosalind Franklin (1920-1958) que são atribuídos, também, os devidos créditos à compreensão da estrutura do ácido desoxirribonucleico (DNA) por ter sido a responsável por parte das pesquisas e descobertas iniciais que levaram Watson e Crick a elaborarem o modelo da dupla hélice para a molécula de DNA, ainda que estes, juntamente com Maurice Wilkins (1916-2004), tenham sido agraciados, quatro anos após a morte da cientista, com o prêmio Nobel por seus estudos. Contudo, sabe-se que o pioneirismo dos cientistas foi baseado nos estudos de Franklin.
} 
Diante do aumento na expectativa devida, o homem se sente motivado em desenvolver métodos que possam contribuir com a longevidade humana, a fim de se atingir índices mais expressivos.

\section{A busca em desacelerar o envelhecimento}

Pesquisadores suíços da Escola Politécnica de Lausanne (EPFL), renomado instituto de pesquisa suíço, deram um passo adiante em favor de revelar o mistério do envelhecimento.

Sabendo que a mitocôndria transforma nutrientes em vários tipos de proteínas, e de que alguns estudos anteriores sugeriram que ela pode ser o motor do envelhecimento, os pesquisadores examinaram-na em camundongos e descobriram três genes que afetam a expectativa de vida deles por conta da velocidade com que funcionam. Ao desacelerarem os genes dos roedores em $50 \%$, observaram que eles viveram 250 dias a mais que os outros camundongos, aumentando em $30 \%$ a expectativa de vida 3 .

Já os pesquisadores da Universidade de Stanford, nos Estados Unidos, procurando por genes ligados à longevidade, examinaram uma população de pessoas dividindo-as em dois grupos: grupo A, com pessoas acima de 90 anos; e grupo $\mathrm{B}$, com pessoas acima de 100 anos. Após examiná-las, descobriram oito genes ligados com a longevidade, dentre os oito genes descobertos, quatro foram confirmados em pessoas com idade entre 100 ou mais. $\mathrm{O}$ estudo constatou que certas variantes dos genes chamados $\mathrm{ABO}, \mathrm{CDKN} 2 \mathrm{~B}$, APOE e $\mathrm{SH}_{2} \mathrm{~B}_{3}$ eram mais comuns em centenários do que em pessoas com uma esperança de vida média, e assim determinaram que a variação genética associada com sangue tipo "O" era mais comum em centenários ${ }^{4}$.

Muitos que adentram em questões relacionadas ao envelhecimento acreditam que o indivíduo envelhece porque foi programado para perecer a fim de abrir espaço para a próxima geração5, isto porque o fatalismo leva-nos a aceitar que o envelhecimento tem de acontecer - porque desgastar-se faz parte da ordem natural das coisas (KIRKWOOD, 2001b, p. 28).

Essa crença de que uma geração foi programada para sucumbir, quando colocada diante de algumas descobertas passa a ser questionada, ainda que as

\footnotetext{
3 GAUCHAZH. Descoberta de cientistas suíços traz avanços para compreender a longevidade. Disponível em: <http://zh.clicrbs.com.br/rs/vida-e-estilo/vida/noticia/2013/05/descoberta-decientistas-suicos-traz-avancos-para-compreender-a-longevidade-4145846.html>. Acesso em: 22 de set. 2020.

4 HYPESCIENCE. Cientistas descobrem novos genes para longevidade. Disponível em: $<$ https://hypescience.com/viver-ate-os-10o-novos-genes-para-longevidade-sao-descobertos/>. Acesso em: 3 de out. 2020.

${ }^{5}$ KIRKWOOD, Tom. The end of age. London: Profile Books, 2001.
} 


\section{XAVIER, T.}

descobertas tenham sido feitas em outros animais, como àquelas feitas em anêmonas marinhas, peixes e tartarugas que envelhecem lentamente.

A água-viva Turritopsis Nutricula, por exemplo, conhecida como imortal por não perecer por causas naturais intrínsecas, só podendo ser morta por interferência externa, quando atingi a maturidade consegue regredir a condição de pólipo num ciclo que acontece permanentemente ${ }^{6}$; a Koi (Cyprinus carpio), também conhecida como carpa chinesa, é uma espécie de peixe que consegue atingir média de vida de 200 anos; enquanto que a tartaruga-rajada consegue atingir média de vida de 180 anos7. Outro exemplo é o molusco que vive em média 400 anos, o Artica islandica, considerado por muitos biólogos como sendo o ser vivo que mais vive no mundo ${ }^{8}$.

Há uma vasta variedade de seres vivos existentes no planeta que quebram a barreira do absurdo e dão aos cientistas a oportunidade de estudarem e compreenderem com mais afinco a longevidade, ainda que muitas das pesquisas sejam pautadas por informações adquiridas a partir de estudos feitos em animais mamíferos e seres marinhos. Todavia, elas são importantes por permitirem o avanço de pesquisas relacionadas ao processo de envelhecimento, podendo contribuir para o elixir da longevidade. Por tudo isso, a busca do homem em desacelerar o envelhecimento vem despertando o desejo de se atingir a imortalidade9.

\section{O desejo de se atingir a imortalidade}

No artigo intitulado $O$ dia em que a morte morrerá ${ }^{10}$, Nahra apresenta o conceito de imortalidade trazido para a cena filosófica por John Harris em Enhancing evolution ${ }^{11}$. Em seu artigo, Nahra mostra (hipoteticamente) que se mantido o aumento constante na expectativa de vida que tem sido observado nos últimos 160 anos, na razão de 12 semanas por ano, se pode esperar que em 40 mil anos, a expectativa de vida seja de aproximadamente 10 mil anos, o que poderíamos caracterizar de imortalidade. Tal ideia pode parecer sonho fictício, mas é um desejo

\footnotetext{
${ }^{6}$ BBC. A misteriosa água-viva de apenas dois centímetros que cientistas acreditam ser imortal. Disponível em: <http://momentocurioso.com.br/turritopsis/>. Acesso em: 22 de mar. 2021.

7 O VERSO DO INVERSO. Os 5 animais com maior expectativa de vida. Disponível em: <http://www.oversodoinverso.com.br/os-5-animais-com-maior-expectativa-de-vida/>. Acesso em: 5 de jun. 2020.

${ }^{8}$ Ibidem.

9 Entende-se "imortalidade" aqui como sendo o prolongamento da existência do corpo, e não a sua indestrutibilidade. Essa imortalidade tem relação apenas com a longevidade. Esta longevidade não exclui a destrutibilidade da matéria (corpo), pois ela (a matéria) é efêmera. Assim sendo, afirmar aqui a "imortalidade" no sentido estrito da palavra é inconcebível, pois para isto teríamos que levar em consideração também a indestrutibilidade, como no caso da imortalidade da alma por ser imaterial. Não à toa Luc Ferry disse que "mesmo que conseguíssemos controlar o envelhecimento do organismo, a morte ainda permaneceria possível em caso de acidente, suicídio ou atentado" (2018, p. 25)

${ }^{10}$ NAHRA, Cinara Maria Leite. O dia em que a morte morrerá. Rev. Veritas - RS. v. 58, n. 1, (2013).

${ }^{11}$ HARRIS, J. Enhancing evolution. New Jersey: Princeton University Press, 2007, p. 64.
} 
que se encontra bastante forte "nos países mais desenvolvidos. Pessoas vivendo mais e com mais saúde é algo que já vem acontecendo" (NAHRA, 2013, p. 90).

Diante de tamanho desejo, a seguinte pergunta surge: o que o futuro nos reserva? Nahra responde dizendo que

[...] não há dúvida que a maior realização de todas as possíveis realizações, aquela que provocaria a mais radical mudança na natureza humana em toda História, seria os seres humanos tornarem-se, um dia, imortais. A nossa transformação em seres verdadeiramente imortais, sendo capazes de viver para sempre, como os deuses da mitologia grega, é algo que talvez não sejamos capazes de atingir. Entretanto, a possibilidade de que os futuros membros da nossa espécie vivam cada vez mais é muito alta. Se nós não vivermos para sempre, mas se as pessoas constantemente atingirem idades de milhares e milhares de anos, estas pessoas poderiam ser consideradas imortais comparativamente a nós (NAHRA, 2013, p. 90).

Para, contudo, se pensar na ideia de uma possível imortalidade do corpo, fazse necessário pensarmos, também, em algumas problemáticas que, se não forem pensadas e discutidas, tal ideia passa a ser uma maldição para a própria raça humana, já que estender a vida traz consigo questões que colocam o homem na condição de pensar se vale a pena ou não continuar na busca da longevidade em prol da imortalidade.

O filósofo alemão Hans Jonas (1903-1993), que desenvolveu trabalhos no campo dos problemas éticos sociais criados pela tecnologia, apresenta em seu trabalho The Burden and Blessing of Immortality, objeções acerca da ideia de extensão da vida. Segundo ele, estender a vida seria algo injusto, pois fere o tempo do ciclo natural da vida: nascimento e morte. O filósofo acredita que prolongar a vida seria sem sentido, por causa do tédio que os homens viveriam em uma vida infinita. $\mathrm{O}$ prolongamento da vida seria sem sentido, também, porque a identidade pessoal do indivíduo não se manteria durante longos períodos de uma existência estendida $^{12}$.

Outra objeção levantada por Hans Jonas para se pensar a ideia de extensão da vida humana é a de que a imortalidade do corpo por meio da longevidade contribuiria para a superpopulação, colocando as pessoas na condição de não mais reproduzirem, uma vez que ele acredita que se a população humana se tornasse imortal e as pessoas continuassem a se reproduzir na mesma velocidade em que se reproduzem hoje, haveria um superpovoamento do planeta, forçando os indivíduos

\footnotetext{
${ }^{12}$ JONAS, H. The burden and blessing of immortality. Hasting Center Report, 22(1), 1992, p. 34-40.
} 
a pararem de se reproduzir a fim de se evitar a superpopulação e a aceleração da degradação do meio ambiente ${ }^{13}$.

Contrariando Hans Jonas e se posicionando a favor das ideias de John Harris em prol da imortalidade, Nahra dirá que a questão acima é significativa, porém, passa a ser uma objeção fraca por

[...] não considerar a variável do avanço tecnológico em sua análise, não levando em consideração que a imortalidade, se for atingível, só poderia sê-la por meio de um longo processo de desenvolvimento tecnológico. A possibilidade de que tenhamos seres humanos vivendo mil anos ainda neste século é mínima e, portanto, a afirmação de que a imortalidade necessariamente vai gerar superpopulação e que a superpopulação necessariamente implicará o fim da reprodução não se configura em problema imediato. $\mathrm{O}$ problema poderia ser gerado a longuíssimo prazo, mas pensado também a longuíssimo prazo se for possível tecnologicamente que prolonguemos bastante o tempo de vida dos humanos, haveremos de pensar na hipótese de que também será possível desenvolver uma tecnologia que permitirá que a espécie humana habite, viva e colonize outros planetas que sejam propícios para a vida e, se assim for, será possível conciliar a imortalidade com a concepção a medida que continuaremos nos reproduzindo e viajando pelo universo com o objetivo de espalhar a vida e, mais especificamente, a vida inteligente no universo (NAHRA, 2013, p. 95).

Essa objeção de superpopulação abre espaço para se cogitar a importância de aprimorar moralmente o homem em prol de preservá-lo de si mesmo, uma vez que este, ao longo da história, mostrou-se (e ainda se mostra) bastante inclinado à destruição de si mesmo. Neste sentido, a imortalidade de um ser propenso a promover desolação resultaria em uma devastação inimaginável. E por isso novas tecnologias estão sendo cotadas para ajudar na compreensão dos mecanismos cerebrais.

A neurociência, por ser uma área que estuda detalhadamente zonas cerebrais ativadas, está despertando a atenção de muitos devido ao fato de poder contribuir para a ideia de aprimoramento do homem, uma vez que esta está engajada na compreensão do funcionamento do cérebro humano.

Para um dos maiores nomes da neurociência na atualidade, o português Antônio Damásio, o homem está evoluindo para conciliar emoção e razão por meio dos estudos da neurociência que ajudam a desvendar a base neurológica das emoções, demostrando que elas têm um papel central na tomada de decisões. E por isso esta área do saber procura identificar quais são os processos que produzem o fenômeno da consciência, adentrando nesta seara por identificar que os sentimentos do ser humano foram fundamentais para a formação do sistema moral (que por sua

${ }^{13}$ JONAS, H. The burden and blessing of immortality. Hasting Center Report, 22(1), 1992, p. 34-40. 
vez é fundamental para a organização da sociedade), carecendo serem estudados e compreendidos em prol da orientação da espécie humana, a fim de que um dia, a convivência do homem em sociedade, que exige que se equilibre razão e emoção o tempo inteiro, possam existir em harmonia ${ }^{14}$.

Dentre inúmeras técnicas da neurociência voltadas para a compreensão das funções cerebrais ligadas às emoções, se destacam as da neuroimagem, a saber, tomografia computadorizada (TC), tomografia por emissão de pósitrons (PET) e a ressonância magnética funcional (RMf) - que vem tentando identificar mecanismos cerebrais que admitam o funcionamento da mente humana com base na observação das áreas ativas enquanto o indivíduo pensa em algo.

A tomografia computadorizada (TC), por exemplo, permite medir a radiodensidade de cada ponto do cérebro por meio de raios-X capazes de produzir feixes bastante estreitos que percorrem ponto a ponto a área a ser visualizada. A TC é uma técnica importante porque ela permite identificar sangue, licor e tecido nervoso, obtendo-se uma boa visualização de áreas maiores de substâncias branca e cinzenta. Já a tomografia por emissão de pósitrons (PET) identifica as alterações do fluxo sanguíneo ao medir alterações na captação de glicose ou oxigênio. Pessoas que são submetidas a esta técnica, por exemplo, recebem uma injeção de isótopos (átomos) que emitem pósitrons (como o flúor, por exemplo) que contribui para o mapeamento e a distribuição do fluxo durante a execução de tarefas, ou seja, localizar áreas corticais ativadas quando o indivíduo recebe um estímulo sensorial ou quando realiza um movimento. Já a ressonância magnética funcional (RMf) permite o mapeamento da função cerebral. Com este tipo de técnica é possível visualizar imagens do cérebro em funcionamento durante a execução da tarefa ${ }^{15}$.

A neurociência espera que nas próximas décadas os pensamentos, sentimentos e emoções sejam desvendados por completo, como também, as suas intensidades. Embora a neurociência seja uma área do saber bastante significativa para a ideia de aprimoramento humano, ela não é a única aposta para este fim, já que a biotecnologia tem avançado expressivamente em descobertas relacionadas à engenharia genética, que é uma de suas áreas que pode contribuir para o melhoramento do homem por meio de escolha das características genéticas. Diante disto, o filósofo e sociólogo alemão Jürgen Habermas, em $O$ futuro da natureza humana, livro que traz uma discussão importantíssima desencadeada pela técnica genética, diz que devido ao progresso da manipulação e decodificação do genoma

\footnotetext{
14 NEUROPSICOPEDAGOGIA. Neurociências em benefício da educação. Disponível em: $<$ http://neuropsicopedagogianasaladeaula.blogspot.com.br/2013/o7/o-homem-esta-evoluindo-paraconciliar.html>. Acesso em: 04 de set. 2020.

15 CIÊNCIA DO CÉREBRO. Os avanços da (neuro)ciência. Disponível em: $<$ https://cienciadocerebro.wordpress.com/2012/o7/11/os-avancos-da-neurociencia/>. Acesso em: 7 de jul. 2020 .
} 
humano, há a esperança de que em breve o homem tomará em suas mãos o curso da sua própria evolução ${ }^{16}$.

Reconhecendo o potencial da biotecnologia e acreditando que ela pode contribuir para a evolução do homem, Nahra, em seu trabalho intitulado $A$ revolução na ética e na metafísica causada pela neurociência, biotecnologia e pelo desenvolvimento tecnológico em geral, diz que

[...] a revolução biotecnológica em pleno curso pode transformar radicalmente a natureza humana. $\mathrm{O}$ prospecto do enhancement, ou seja, do aprimoramento humano através de meios biotecnológicos, pode produzir a transformação mais radical, e talvez a mais rápida até agora acontecida na espécie humana (NAHRA, 2015, p. 13)

Por tudo isso, a ciência e a tecnologia são vistas como potencialmente capazes de contribuírem para o aprimoramento do homem em prol da sua evolução sem que este continue a ser um tropeço, dada as suas limitações.

\section{Considerações finais}

Embora a imortalidade do corpo por meio da longevidade ainda esteja na escala das ideias, paira na mente de muitos a convicção de que com o processo de modernização causado pela ampliação tecnológica, é possível que tal ideia um dia se concretize. E é por isso que adentramos nesta seara que traz consigo questões que nos colocam na condição de perguntar: o aprimoramento do homem será capaz de proporcionar, verdadeiramente, o baluarte restituidor da civilização humana? Seu plano é de fato aprimorar o homem em prol da superação de uma menoridade estrutural? Seus objetivos terão a capacidade de reinventar uma civilização marcada por imperfeições que por vezes geram hecatombes, cataclismos? Essas questões são fundamentais para imergirmos com mais profundidade no campo das discussões ligadas ao aprimoramento humano, no entanto, procuraremos respondê-las em momento oportuno.

\section{Referências}

BBC. A misteriosa água-viva de apenas dois centímetros que cientistas acreditam ser imortal. Disponível em: <http://momentocurioso.com.br/turritopsis/>. Acesso em: 22 de mar. 2021.

CIÊNCIA DO CÉREBRO. Os avanços da (neuro)ciência. Disponível em: $<$ https://cienciadocerebro.wordpress.com/2012/o7/11/os-avancos-da-neurociencia/>. Acesso em: 7 de jul. 2020.

ESCOBAR, H. Jornal da ciência. Recife - PE (2004). Disponível em: <http://www.renorbio.org.br/portal/noticias/descoberta-de-watson-e-crick-foi-a-pedrafundamental-da-genetica.htm>. Acesso em: 10 de out. 2020.

\footnotetext{
${ }^{16}$ HABERMAS, J. O futuro da natureza humana: a caminho de uma eugenia liberal?. Tradução de
} Karina Jannini. São Paulo: Martins Fontes, 2010. 
FERRY, L. A revolução transumanista. Tradução de Éric R. R. Heneault. Barueri - SP: Manole, 2018.

GAUCHAZH. Descoberta de cientistas suíços traz avanços para compreender a longevidade. Disponível em: <http://zh.clicrbs.com.br/rs/vida-e-estilo/vida/noticia/2013/o5/descobertade-cientistas-suicos-traz-avancos-para-compreender-a-longevidade-4145846.html>. Acesso em: 22 de set. 2020.

HARRIS, J. Enhancing evolution. New Jersey: Princeton University Press, 2007, p. 64.

HABERMAS, J. O futuro da natureza humana: a caminho de uma eugenia liberal?. Tradução de Karina Jannini. São Paulo: Martins Fontes, 2010.

HYPESCIENCE. Cientistas descobrem novos genes para longevidade. Disponível em: $<$ https://hypescience.com/viver-ate-os-10o-novos-genes-para-longevidade-saodescobertos/>. Acesso em: 3 de out. 2020.

JONAS, H. The burden and blessing of immortality. Hasting Center Report, 22(1), 1992, p. 3440.

KIRKWOOD, T. The end of age. London: Profile Books, 2001.

. Os melhores anos de nossas vidas. Tradução de Ruy Jungmann. Rio de Janeiro: Record, 2001.

NAHRA, Cinara Maria Leite. O dia em que a morte morrerá. Rev. Veritas - RS. v. 58, n. 1, (2013).

A revolução na ética e na metafísica causada pela neurociência, biotecnologia e pelo desenvolvimento tecnológico em geral. Dossiê Naturalismo - UFPE, 2015. Volume suplementar 02.

NEUROPSICOPEDAGOGIA. Neurociências em beneficio da educação. Disponível em: $<$ http://neuropsicopedagogianasaladeaula.blogspot.com.br/2013/o7/o-homem-estaevoluindo-para-conciliar.html>. Acesso em: 04 de set. 2020.

O VERSO DO INVERSO. Os 5 animais com maior expectativa de vida. Disponível em: <http://www.oversodoinverso.com.br/os-5-animais-com-maior-expectativa-de-vida/>. Acesso em: 5 de jun. 2020.

Submissão: 27. 03. 2021 / Aceite: 15. 06. 2021 